\title{
Risk factors for postoperative recurrence of Crohn's disease with emphasis on surgical predictors
}

\author{
Antonios Gklavas, Dionysios Dellaportas, loannis Papaconstantinou \\ Aretaieion University Hospital, University of Athens, School of Medicine, Athens, Greece
}

\begin{abstract}
Intestinal resection for Crohn's disease is not curative and postoperative recurrence rates remain high. Early detection of indices associated with recurrence and risk stratification are fundamental for the postoperative management of patients. Early endoscopy at 6-12 months is the "gold standard" procedure, whereas other modalities such as fecal calprotectin and imaging techniques can contribute to the diagnosis of recurrence. The purpose of this review is to summarize current data regarding risk factors correlated with postoperative relapse. Smoking is a well-established, modifiable risk factor. There are sufficient data that correlate penetrating disease, perianal involvement, extensive resections, prior surgery, histological features (plexitis and granulomas), and improper management after resection with high rates for recurrence. The literature provides conflicting data for other possible predictors, such as age, sex, family history of inflammatory bowel disease, location of disease, strictureplasties, blood transfusions, and postoperative complications, necessitating further evidence. On the other hand, surgical factors such as anastomotic configuration, open or laparoscopic approach, and microscopic disease at specimen margins when macroscopic disease is resected, seem not to be related with an increased risk of recurrence. Further recognition of histological features as well as gene-related factors are promising fields for research.
\end{abstract}

Keywords Crohn's disease, recurrence risk factors, postoperative recurrence

Ann Gastroenterol 2017; 30 (6): 1-15

\section{Introduction}

Crohn's disease $(\mathrm{CD})$ is a chronic inflammatory process that can affect any part of the gastrointestinal tract, while $25-40 \%$ of patients will experience extraintestinal manifestations [1]. Natural history data suggest that the course of the disease is characterized by relapses and remissions, while the majority of patients will present complications such as bleeding, strictures, fistulas and abscesses that demonstrate a disabling progression [2].

Surgical intervention will be required in about $80 \%$ of patients during their lifetime and, even in the biologic agent treatment era,

$2^{\text {nd }}$ Department of Surgery, Aretaieion University Hospital, University of Athens, School of Medicine, Athens, Greece

Conflict of Interest: None

Correspondence to: Antonios Gklavas, MD, $2^{\text {nd }}$ Department of Surgery, Aretaieion University Hospital, Vasilissis Sofias 76 11528, Athens, Greece, e-mail: agklavas@gmail.com

Received 15 May 2017; accepted 10 July 2017; published online 26 September 2017

DOI: https://doi.org/10.20524/aog.2017.0195 the requirement for intestinal resection remains high [3]. However, a recent meta-analysis of population-based studies demonstrated that, over the last 6 decades, there has been a decrease in the number of patients with $\mathrm{CD}$ who will require intestinal surgery at 1, 5 and 10 years after diagnosis [4]. Factors such as earlier diagnosis, implementation of practice guidelines, continuing medical education for inflammatory bowel disease (IBD) and early use of immunomodulators/anti-tumor necrosis factor (TNF) therapies seem to have contributed to this reduction [4-6].

Given the nature of the disease, surgical treatment is not curative and the rates of postoperative recurrence (POR) are high: endoscopic recurrence in the first postoperative year is reported in $35-85 \%$ of cases, with $10-38 \%$ of patients being symptomatic. By the third year, the rates are $85-100 \%$ and $34-$ $86 \%$ respectively [7]. Froklis et $a$, in a recent meta-analysis of population-based studies, found that the overall risk for a second surgical intervention reaches a total of $28.7 \%$ : the risk in the $5^{\text {th }}$ and $10^{\text {th }}$ year was $24.2 \%$ and $35 \%$, respectively. The same study demonstrated a significant difference between studies conducted before 1980 compared to those conducted after 1980, which could be attributed to better postoperative care and treatment options for CD patients [8]. The purpose of this article is to review the risk factors associated with POR after intestinal resection. 


\section{POR}

POR is defined in several ways: endoscopic, biochemical, radiographic, histological, clinical, and surgical. The pattern is well-described: endoscopic recurrence precedes clinical relapse of symptoms, whereas the need for a second surgical intervention is referred to as surgical recurrence [9]. Thus, the diagnosis of POR may be based on endoscopic findings, serum or fecal markers, imaging findings, or clinical symptoms.

\section{Endoscopy}

Endoscopy is considered to be the "gold standard" for the early detection of POR. Rutgeerts et al created a 5-level scale, based on the severity of the endoscopy findings at the anastomotic site and neoterminal ileum (Table 1). Patients with scores i0-i1 had a better prognosis, exhibiting $<10 \%$ recurrence 10 years after surgery, demonstrating that the severity of the lesions is related to the course of the disease [10]. Endoscopic recurrence is defined as a Rutgeerts score $\geq i 2$. A number of studies have tried to demonstrate the utility of early ileocolonoscopy, 6-12 months after index surgery, in terms of offering the patients an endoscopy-based management [11]. The landmark POCER trial concluded that the early detection of POR, followed by a step-up treatment approach according to the severity of endoscopic findings, is better than medication alone for preventing clinical relapse [12].

However, a number of issues regarding the Rutgeerts score should be taken under consideration. Firstly, it has not been validated prospectively, although it was used by several studies evaluating POR [13]. Secondly, according to a Spanish study, patients with score i2 having lesions confined to the anastomosis (i2a) were at lower risk for developing endoscopic progression or clinical recurrence compared to patients with non-anastomotic (ileal) lesions (i2b). According to the authors, anastomotic ulceration (i2a) could be attributed to surgeryrelated factors, such as sutures or ischemia, rather than a "true" endoscopic POR [14]. In contrast, a recent study by Bayart did not demonstrate a difference in clinical POR rates between the two subgroups [15]. Thus, further data relating to this issue are necessary. Lastly, the level of interobserver agreement might have been overestimated in the past [16]. A recent study found that interobserver agreement was moderate, especially for distinguishing scores $<\mathrm{i} 2$ from those $\geq \mathrm{i} 2$, which could lead to inappropriate therapeutic management in about $13 \%$ of patients [17]. At present, wireless capsule endoscopy is a good option for POR detection in areas inaccessible via colonoscopy or when colonoscopy is contraindicated or unsuccessful $[18,19]$.

\section{Fecal calprotectin}

Fecal calprotectin is a useful biomarker for POR detection. Evidence suggests that it correlates closely with the severity of endoscopic findings, and could be used for monitoring the response to treatment after POR $[20,21]$. It has been proposed by some authors as a useful screening test postoperatively (in conjunction with serum C-reactive protein [CRP] or not), for selecting patients to undergo endoscopy [22,23]. This evaluation could reduce the number of endoscopies needed for patients' follow up, without this currently being established in clinical practice. Nevertheless, a clear cutoff point has not so far been determined [24].

\section{CD activity index (CDAI)}

In contrast, CDAI score does not have a satisfactory correlation with endoscopic recurrence according to Regueiro et al [25]. Therefore, given that the symptoms of patients after ileocecal resection may vary (from episodes of partial obstruction due to adhesions to diarrhea due to malabsorption), the term "clinical relapse" should refer to patients with confirmed endoscopic lesions and recurrence of symptoms [18,26]. Likewise, CRP, erythrocyte sedimentation rate, as well as other serological markers (leukocytes, platelet cells, fibrinogen, etc.) have poor negative predictive values, rendering them ineffective for the exclusion of POR [27]. Data have shown their unreliability for discriminating Rutgeerts score $<\mathrm{i} 2$ from $\geq \mathrm{i} 2$ [28], whereas Papamichael et al found that elevated CRP could identify only severe endoscopic POR (Rutgeerts score i3/i4) [29].

\section{Imaging}

Imaging techniques such as ultrasonography, computed tomography (CT), magnetic resonance imaging (MRI) have been used for POR detection. Transabdominal ultrasound is a noninvasive, inexpensive diagnostic tool, free of ionizing radiation. The bowel wall thickness near the site of anastomosis is associated with the endoscopic findings [30,31]. CT enterography and MR enterography show similar sensitivity and diagnostic accuracy for POR, both demonstrating high agreement with endoscopic findings [18,32,33]. Currently, imaging modalities are only complementary to endoscopy.

\section{Risk factors for POR}

For the purposes of this review, the risk factors for POR will be divided into five groups (Table 2):

\section{Patient-related factors}

\section{Smoking}

Tobacco smoking is, for many reasons, aggravating for $\mathrm{CD}$ patients: it is a factor that could trigger the disease in 
Table 1 Severity of postoperative endoscopic findings in ileocolonic anastomosis (Rutgeerts' score) [10]

\begin{tabular}{|c|c|}
\hline Score & Endoscopic lesions \\
\hline i0 & Absence of lesions \\
\hline i1 & $\leq 5$ aphthous ulcers \\
\hline i2 & $\begin{array}{l}>5 \text { aphthous ulcers with normal intervening mucosa, } \\
\text { skip areas of larger lesions, or lesions confined to } \\
\text { ileocolonic anastomosis }\end{array}$ \\
\hline i3 & Diffuse aphthous ileitis with diffusely inflamed mucosa \\
\hline $\mathrm{i} 4$ & $\begin{array}{l}\text { Diffuse inflammation with larger ulcers, nodules and/ } \\
\text { or narrowing }\end{array}$ \\
\hline
\end{tabular}

Rutgeerts' score $\geq \mathrm{i} 2$ defines endoscopic recurrence

Table 2 Potential risk factors for postoperative recurrence

\begin{tabular}{ll}
\hline Patient-related & Smoking \\
& Sex \\
& IBD family history \\
Disease-related & Age \\
& Duration before first surgery \\
& Location of disease \\
& Behavior of disease \\
& Perianal disease \\
Surgery-related & Type of anastomosis \\
& Extent/margins of resection \\
& Laparoscopic/open surgery \\
& Strictureplasty \\
& Postoperative complications \\
& Blood transfusions \\
& Prior resections \\
& Plexitis \\
& Granulomas \\
Histology-related & Lymphatic vessel density \\
& NOD2/CARD15 \\
IL-10 promoter \\
IRGFM \\
Gene-related & SARD18 \\
\end{tabular}

IBD, inflammatory bowel disease; NOD2/CARD15, Nucleotide-binding oligomerization domain 2 / caspase activation and recruitment domain 15; IL10, interleukin-10; IRGFM, immunity-related GTPase family M; CARD8, caspase recruitment domain-containing protein 8; SMAD3, mothers against decapentaplegic homolog 3

genetically predisposed individuals, accelerate the progression of the disease (shortening the interval between diagnosis and need for treatment with biological/immunomodulators/ steroids or surgery), as well as increasing the risk of complications and causing frequent relapses and extraintestinal manifestations [34-36].

Cigarette smoking is a well-recognized risk factor for POR and the only modifiable one; several studies have assessed the effect of smoking on recurrence [37-40]. Cottone et al, evaluating several variables as potential risk factors for POR in a study of 182 patients, demonstrated smoking (Odds Ratio [OR] 2.2, 95\% Confidence Interval [CI] 1.2-3.8) along with extent of disease (OR 2.6, 95\%CI 1.0-6.7) as the only predictive factors for endoscopic POR. As for clinical recurrence, smoking
(Hazzard Ratio [HR] 1.46, 95\%CI 1.1-1.8), extraintestinal manifestations (HR 1.61, 95\%CI 1.0-2.5) and extent of disease (HR 1.57, 95\%CI 1.0-2.4) were independent predictive factors, whereas surgical recurrence was associated with smoking only (HR 2.0, 95\%CI 1.2-2.3) [41]. Unkart et al, in a retrospective observational study of 176 patients who underwent ileocolonic resection, demonstrated an increased risk for a second ileocolectomy ( $\mathrm{HR}$ 2.08, 95\%CI 1.11-3.91, $\mathrm{P}=0.023$ ) for smokers at the time of first operation [42].

A recent multicenter observational study by de Barcelos, as well as a Swiss IBD cohort study, failed to recognize smoking as a risk factor for early postoperative endoscopic recurrence and repetitive ileocolonic resections. According to the authors of the former study, this could be partially explained by the small number of patients recruited $(n=127)$, including only $15 \%$ smokers. As for the latter, this result could be explained by the lack of $23 \%$ and $16 \%$ of smoking data at diagnosis and follow up respectively $[43,44]$.

The relation between cigarette cessation and postoperative course has been evaluated by several studies. Ryan et al, recruiting 267 patients, demonstrated that smoking cessation in patients with ileocecal disease could reduce the incidence of surgical recurrence. Ex-smokers when compared to nonsmokers had no significant difference in the risk for reoperation and disease-free intervals after the first resection [45]. A metaanalysis of 16 observational studies including 2692 patients between 1990 and 2007 demonstrated that, when compared to non-smokers, ex-smokers had no significant difference in terms of clinical and surgical recurrence at 10 years. Moreover, the latter study confirmed that smokers face a 2 -fold increased risk for clinical and a 2.5-fold increased risk for surgical recurrence at 10 years [46]. Timmer et al reached the same conclusions, as did a recent meta-analysis $[35,47]$. These results provide convincing evidence that smoking cessation has a beneficial effect over the postoperative course of $\mathrm{CD}$, reducing the risk of POR to the levels of non-smokers.

Another issue that has been assessed in the literature is the dose-response effect of cigarette smoking. According to Yamamoto's study of 141 patients who underwent ileocolonic resection, heavy smokers (defined as smoking $>15$ cigarettes per day) had significantly higher overall recurrence rates compared to mild smokers ( $77 \%$ vs. $45 \%, \mathrm{P}=0.02$ ) [39]. Likewise, Lindberg et al, defining arbitrarily high exposure to tobacco smoking (>150 cigarette years) and heavy smoking ( $>10$ cigarettes per day), demonstrated a greater probability for reoperation in heavy smokers [48]. On the other hand, Ryan could not demonstrate a definite effect, either for dose-response or for years of smoking, on surgical recurrence rates [45].

\section{Sex}

Sex has not been established as a risk factor. It has been evaluated in several studies, but outcomes are conflicting. Searching the literature, we found studies demonstrating either male [49] or female [50] sex as a predictive factor for POR, whereas the majority of authors found no differences in recurrence rates $[43,44,51,52]$. 


\section{Family history of IBD}

Regarding the impact of IBD history on POR rate, the evidence from a search of the literature is also quite unclear. For example, Unkart's study demonstrated a higher risk for patients with a positive family history (HR 2.24, 95\%CI 1.16-4.30, $\mathrm{P}=0.016$ ) [42], as did a study by Ryan et al [45]. In contrast, Kurer et al [52] found no additional risk according to IBD history. Thus, further data are required to clarify the relation of positive family history to recurrence rates.

\section{Disease-related factors}

The Montreal classification (Table 3) separates CD patients according to the age at onset (A), disease location (L), and disease behavior (B) [53]. This classification reflects the wide spectrum of the CD phenotype, where each different subtype could be associated with different pathophysiological mechanisms, response to medical treatment, type of complications or disease aggressiveness, need for surgical intervention and POR [54].

\section{Age at diagnosis and duration of disease before first surgery}

Younger age at diagnosis is considered to be a major factor for a more aggressive and disabling course, according to a review by Blonski et al [55]. However, the effect on POR is less clear, and data extracted from the literature do not consistently indicate age as a predictive factor [10,43,45,56-58].

Duration of disease before first surgery has also been evaluated by several studies. Yamamoto et al, after dividing the duration into arbitrary intervals of less than 1 year, 1-10 years, and more than 10 years, came to the conclusion that short duration was related to high POR rates [59]. Many studies have supported this observation [38,60-62], whereas others have not $[58,63]$.

\section{Location of disease}

A recent study by Manser et al, collecting data from 305 patients, demonstrated that an ileal location of $\mathrm{CD}$ (Montreal-L1) is a predictive factor (OR 2.42, 95\%CI 1.02-

Table 3 Montreal classification for Crohn's disease phenotype [53]

\begin{tabular}{lll}
$\begin{array}{l}\text { Age at } \\
\text { diagnosis (A) }\end{array}$ & $\begin{array}{l}\text { Location of } \\
\text { disease (L) }\end{array}$ & Behavior of disease (B) \\
\hline A1: $\leq 16$ years & L1: ileal & B1: non-stricturing/non- \\
A2: $17-40$ & L2: colonic & penetrating \\
years & L3: ileocolonic & B2: stricturing \\
A3: $>40$ years & $\begin{array}{l}\text { L4: modifier for } \\
\text { upper }\end{array}$ & B3: penetrating \\
& $\begin{array}{l}\text { gastrointestinal } \\
\text { tract }\end{array}$ & $\begin{array}{l}\text { p: modifier for perianal } \\
\text { disease }\end{array}$ \\
\hline
\end{tabular}

5.78, $\mathrm{P}=0.05$ ) for a second ileocolonic resection [44]. A study of 280 patients in the John Radcliffe Hospital, Oxford, UK, concluded that patients with ileal disease had significantly higher POR rates compared to patients with ileocolonic (Montreal-L2) or colonic disease (Montreal-L3) [63]. Likewise, in a population-based study in The Netherlands, small bowel location of the disease was a predictive factor for POR [64]. Some authors correlate ileocolonic disease with high recurrence rates, as did Morar et al from St Mark's Hospital, $\mathrm{UK}$, in a retrospective analysis of 142 patients $[65,66]$. Keh et al demonstrated that patients with jejunal CD had higher surgical recurrence rates at years 3 and 5 , whereas the 10 -year difference did not reach statistical significance [67].

Two studies reported an upper gastrointestinal location as a significant risk factor for surgical recurrence $[64,68]$, whereas a recent population-based Danish cohort could not confirm this correlation [69]. To our knowledge, only one study has shown that colonic location (Montreal-L3) is related with higher recurrence rates compared to small bowel and ileocolonic disease [70]. Finally, a number of studies have shown no correlation between disease location and POR [43,60,71]. Thus, the data from the literature remain quite conflicting, although disease of the small bowel and ileo-colon seems to increase the risk for POR.

\section{Behavior of disease}

A penetrating phenotype (Montreal-B3), is associated with early POR, according to data extracted from many studies [71-74]. Sachar et al's cohort of 34 patients who underwent ileocolonic resection demonstrated that those with B3 disease had a significantly increased risk for early POR (defined by the authors as clinical recurrence $<3$ years after index operation). In fact, none of the stricturing phenotype patients (Montreal-B2) in that study had symptoms of POR 3 years after ileocolectomy [72]. Likewise, Avidan's retrospective study of 86 patients, defining POR as the need for reoperation (surgical POR), concluded that penetrating disease was a significant risk factor for POR, correlated with a shorter interval to recurrence compared to smoking [71]. Other studies did not demonstrate significant differences in perforating versus non-perforating behavior $[60,75]$. A retrospective study by Yamamoto et al of 165 patients with ileocecal disease suggested that penetrating disease usually reappears with the same behavior, but no additional risk for POR could be documented [75].

This issue has been assessed by two meta-analyses. Similis et al, evaluating 13 studies with 3044 patients, despite the remarkable heterogeneity between studies, concluded that a perforating phenotype was associated with an increased risk of POR (HR 1.50, 95\%CI 1.16-1.93, $\mathrm{P}=0.002$ ). The authors also confirmed the finding of Yamamoto et al, demonstrating that penetrating disease reappears as penetrating, whereas non-penetrating recurs as non-penetrating disease [76]. A second meta-analysis of 12 studies by Pascua et al correlated perforating behavior as a risk factor for endoscopic POR (OR 1.59, 95\%CI 1.37-1.84, $\mathrm{P}<0.05$ ). As in the former study, 
significant heterogeneity was found between the studies included [77]. Therefore, the European Crohn and Colitis Organization (ECCO) includes fistulizing phenotype among the risk factors for POR in the recently published consensus on diagnosis and management of CD [78].

\section{Perianal disease}

Perianal involvement is widely accepted as a risk factor by many authors $[73,79,80]$, as well as the ECCO consensus published in 2016. In a recent Korean study, 132 patients were recruited and divided according to the presence or absence of perianal lesions. It was found that perianal disease was an independent risk factor for abdominal reoperation (HR 1.98, 95\%CI 1.033.78, $\mathrm{P}=0.039$ ) [79]. In concordance of this correlation was an earlier population-based cohort study of 907 patients, according to which patients with perianal disease had a relative risk of 1.6 (95\%CI 1.2-2.3, $\mathrm{P}=0.003)$ for POR [80].

\section{Surgery-related factors}

\section{Type of anastomosis}

According to Vantrappen and Rutgeerts, $90 \%$ of lesions that define endoscopic recurrence are located in the neoterminal ileum or the anastomotic site [81]. Furthermore, Rutgeerts evaluated the association of fecal stream with POR: he followed 5 patients who underwent ileocolectomy with a diverting ileostomy. Six months later, there was no sign of either endoscopic or histological recurrence. In contrast, 6 months after ileostomy reversal, all patients had endoscopic lesions and histological findings showing POR. Moreover, 53 of 75 patients whose ileocolonic anastomosis was not diverted developed endoscopic lesions within the same time frame [82]. As a result, many studies have focused on the effect of anastomotic configuration on POR rates. These data have raised concerns among surgeons as to what type of anastomosis could restore intestinal continuity in a more "anatomical" way, minimizing fecal stasis, ileocolonic reflux, ischemia and bacterial overgrowth in the non-terminal ileum $[83,84]$.

Many studies have proposed a wide lumen side-to-side anastomosis (SSA) as the configuration which is less correlated with POR than other techniques [85-88]. A retrospective study of 141 patients by Scarpa et al has shown that stapled SSA is related to lower reoperation rates, in comparison with end-to-side anastomosis, but the risk for POR when compared to hand-sewn SSA is not significantly different [85]. Another study that included 138 patients in two IBD centers demonstrated that stapled SSA is associated with lower clinical and surgical recurrence rates compared to hand-sewn end-toend anastomosis (EEA) [88]. On the other hand, a randomized controlled trial by McLeod et al showed no significant difference for recurrence rates between SSA and EEA. Of the 170 patients recruited, data could be extracted for 139 who underwent the proper follow up. Endoscopic recurrence at 12 months was $42.5 \%$ for EEA and $37.9 \%$ for SSA $(\mathrm{P}=0.55)$, whereas clinical recurrence was $21.9 \%$ and $22.7 \%$, respectively $(\mathrm{P}=0.92)$ [89]. Likewise, a meta-analysis by Simillis et al of 8 studies including 661 patients demonstrated a higher rate of perioperative morbidity for EEA, but in terms of perioperative recurrence and reoperation no significant difference was documented [90]. A recent multicenter observational study by de Barcelos et al found no correlation between the type of anastomosis and early postoperative endoscopic recurrence [43].

A novel technique for restoring intestinal continuity has been proposed by Kono et al. The Kono-S anastomosis is an antimesenteric, functional EEA. The principals of constructing the Kono-S configuration consist of dividing the mesentery near the bowel wall in order to have minimal devascularization and denervation, dividing the bowel with linear staplers, then suturing the stapled lines of proximal and distal stump to form a supporting column, performing a longitudinal enterotomy at the antimesenteric site in the proximal and distal segments ( $1 \mathrm{~cm}$ from supporting column) and creating the anastomosis with transverse suturing of the two compartments [91]. Preliminary data from 187 patients in USA and Japan, with a median follow up of 32 and 65 months, respectively, indicate that this wide-lumen type of anastomosis has low recurrence rates [92].

To date, none of the anastomotic configurations is considered a risk factor for POR. Nevertheless, new data are needed, especially from randomized studies evaluating all kinds of anastomotic configuration, including the novel Kono-S technique [93].

\section{Extent and margins of the resection}

It was considered for many decades that aggressive surgery, trying to resect not only macroscopically, but also microscopically involved bowel, was fundamental for reducing POR rates $[94,95]$. This trend had an obvious impact on the risk of short-bowel syndrome related to CD [96]. The randomized controlled trial by Fazio et al published in 1996 was a landmark that changed the surgical practice for CD patients. Surgical recurrence was the primary endpoint for patients divided randomly into two groups: 75 patients had limited resection margins (2 cm from macroscopically diseased bowel), whereas 56 patients had wide margins $(12 \mathrm{~cm})$. The patients with limited resection margins did not have a significantly greater POR rate, even if histological findings demonstrated microscopic disease [97]. At present, it is widely accepted that a clear macroscopic margin of $2 \mathrm{~cm}$ is adequate for patients who undergo intestinal resection [78].

The length of resected bowel is not consistently correlated with POR rate. The literature provides conflicting data, since some authors consider that wide resections (when necessary according to preoperative disease extent) are related with higher POR rates, whereas others do not $[80,83,98]$. In spite of this inconsistency, the ECCO has declared extensive bowel resection of $>50 \mathrm{~cm}$ to be a predictive factor for POR [78]. 


\section{Laparoscopic versus open surgery}

Laparoscopic surgery provides the well-established advantages of better cosmesis, and shorter durations of recovery and hospitalization of patients who undergo abdominal surgery. Furthermore, it seems to be as safe as a conventional open procedure for CD patients [99]. Therefore, laparoscopic surgery is the procedure of choice for surgeons who have acquired the proper experience and technical skills. In terms of POR, strong evidence suggests that neither the open nor the laparoscopic technique is associated with high recurrence rates. Stocchi et al, in 2008, analyzed the long-term outcomes of 56 patients who were included in Milsom's ( $n=60)$ randomized controlled trial back in 2001. It was demonstrated that recurrence rate was not affected by the surgical procedure (laparoscopic versus open) [100,101]. Likewise, Eshuis et al, in 2010, published the long-term follow up from 55 patients who were randomized for laparoscopic or open resection in Maartense's trial $(n=60)$ in 2006. Once again, neither of the two procedures was associated with a higher recurrence rate $[102,103]$. A recent meta-analysis of 34 studies by Patel et al confirmed the results of Stocchi and Eshuis [104].

\section{Strictureplasty}

Through the last decades, surgeons have tended to follow a more conservative approach regarding the management of stricturing CD. Strictureplasties, historically divided into "conventional" (Heineke-Mikulicz [HM], Finney) for relatively short strictures ( $<10 \mathrm{~cm}$ for HM, 10-25 cm for Finney) and "nonconventional" techniques (Michelassi, several modifications of "conventionals") for longer strictures, are increasingly used by surgeons. If there is no contraindication (severe inflammation, septic complications at the stricture site, suspicion of cancer, hypoalbuminemia, possibility for suturing under tension, resection of an adjacent bowel segment), strictureplasties are safe and valuable bowel-sparing procedures [105-107]. Mainly performed for small bowel strictures, a number of studies of ileocecal or ileocolonic strictureplasties are being published with limited data for long-term outcomes [108,109].

Dietz et al, in 2002, published a retrospective study of 123 patients who underwent strictureplasty with a median follow up of 6.7 years, finding a $29 \%$ rate of surgical recurrence, whereas diffuse jejunoileitis was not related with a higher risk compared with limited small bowel disease [110]. In contrast, another study evaluating 88 patients (339 strictureplasties), found that the number of strictures, and the number of strictureplasties performed, were correlated with higher rates of surgical recurrence [111]. Sampietro et al followed 102 patients who underwent non-conventional procedures, finding clinical and surgical recurrence at 10 years of $43 \%$ and $27 \%$, respectively. Remarkably, in only $0.8 \%$ was the POR at the strictureplasty site [112]. Recently, in another Italian study (83 patients) assessing side-to-side isoperistaltic strictureplasty, the rate of strictureplasty-site POR was $28.9 \%$ [113].
A meta-analysis by Tichansky et al (506 patients, 1825 strictureplasties), demonstrated that HM strictureplasty was associated with higher recurrence rates compared to the Finney technique, whereas another study suggested the non-inferiority of conventional versus non-conventional techniques in terms of POR [114,115]. In 2007, Reese et al, in a meta-analysis of seven studies (688 patients) comparing strictureplasty alone $(n=311)$ with resection $(n=377)$, found higher surgical recurrence rates for the strictureplastyalone group (38\% vs. $31 \%$; OR 1.36, 95\%CI 0.96-1.93), but the difference was not statistically significant $(\mathrm{P}=0.09)$. The clinical recurrence rates were $17.6 \%$ and $11.5 \%$, respectively $(\mathrm{P}=0.84)$. Moreover, the same study associated strictureplasty alone with lower postoperative morbidity, although statistical significance was again not reached $(\mathrm{P}=0.13)$ [116]. According to Yamamoto's meta-analysis of 1112 patients, overall POR was $23 \%$, of which only $10 \%$ occurred at the strictureplasty site [117]. Since there are no data from randomized trials comparing either resection with strictureplasty, or the different techniques of strictureplasty, current evidence suggests that strictureplasty, in properly selected patients, is a safe procedure with acceptable POR rates.

\section{Postoperative complications/blood transfusion}

Data do not support a constant correlation between postoperative complications and POR $[43,60,85]$. A recent multicenter observational study of early endoscopic recurrence does not suggest an increased risk [43], whereas Scarpa's retrospective study concluded that postoperative complications are associated with significant risk for POR [85].

On the other hand, the immunosuppressive effect of blood transfusion has been assessed by several studies as a possible protective factor against POR. Early studies have demonstrated conflicting results. Some authors found a definite protective effect [118,119], whereas others did not $[120,121]$. A pooled analysis of 4 studies in 1995 by Hollaar et al, including 622 patients with a mean follow up of 72.8 months, concluded that the protective effect of blood transfusion in POR could not be documented [122]. Recent data also fail to demonstrate a clear benefit [43]. A recent cohort of 318 patients from the Cleveland Clinic, USA, demonstrated that blood transfusions were associated with an increased risk for endoscopic (HR 2.08, 95\%CI 1.38-3.14, $\mathrm{P}<0.001)$ and surgical (HR 3.43, 95\%CI 1.92-6.13, $\mathrm{P}<0.001)$ recurrence [123].

\section{Prior resections}

Previous intestinal resections are considered a risk factor for POR according to the recent European guidelines [78]. Ng et el, from St. Mark's Hospital, UK, retrospectively studied 99 patients and demonstrated that previous surgery was a borderline statistically significant risk factor for 
POR ( $\mathrm{P}=0.06)$ [124]. In 2009, McLeod's randomized trial (139 patients) reported an OR 1.78 (95\%CI 1.06-2.90, $\mathrm{P}=0.028)$ for endoscopic and an OR 2 (95\%CI 1.14-3.60, P=0.0016) for surgical recurrence in patients with previous resections [89]. Key studies assessing surgery-related risk factors are presented in Table 4.

\section{Histology-related factors}

\section{Plexitis}

Many studies have assessed the relationship between the inflammatory infiltrates to the submucosal and myenteric

Table 4 Key studies evaluating surgery-related factors for POR

\begin{tabular}{|c|c|c|c|c|c|c|}
\hline Study & Year & Study design & $\begin{array}{c}\text { No of } \\
\text { patients }\end{array}$ & $\begin{array}{l}\text { Mean follow } \\
\text { up (years) }\end{array}$ & $\begin{array}{l}\text { Potential risk factors } \\
\text { evaluated }\end{array}$ & Results \\
\hline Li et al [123] & 2015 & $\begin{array}{l}\text { Single-center } \\
\text { retrospective }\end{array}$ & 318 & 6.1 & $\begin{array}{l}\text { Blood transfusion as a } \\
\text { protective factor against } \\
\text { POR } \\
\text { Others: sex, age, disease } \\
\text { duration, disease } \\
\text { phenotype, smoking } \\
\text { status, perianal disease, } \\
\text { family history of CD, EIM, } \\
\text { postoperative use of anti- } \\
\text { TNF, use of corticosteroids } \\
\text { or immunosuppressive } \\
\text { agents before or after } \\
\text { surgery, indication } \\
\text { for surgery, open vs. } \\
\text { laparoscopic approach, } \\
\text { anastomotic configuration, } \\
\text { intraoperative finding of } \\
\text { fistula/abscess }\end{array}$ & $\begin{array}{l}\text { Blood transfusions } \\
\text { did not protect against } \\
\text { endoscopic/surgical } \\
\text { POR rates; contrariwise } \\
\text { an increased risk } \\
\text { for endoscopic and } \\
\text { surgical POR rates was } \\
\text { demonstrated } \\
\text { Family history of CD, } \\
\text { younger age, perianal } \\
\text { disease were predictors } \\
\text { for endoscopic POR } \\
\text { Family history of CD, } \\
\text { EIM, intraoperative } \\
\text { finding of abscess were } \\
\text { predictors for surgical } \\
\text { POR }\end{array}$ \\
\hline Eshuis et al [103] & 2010 & $\begin{array}{l}\text { Multicenter } \\
\text { RCT }^{*}\end{array}$ & 55 & 6.7 & $\begin{array}{l}\text { Surgical procedure: } \\
\text { Patients were randomized } \\
\text { to laparoscopic-assisted or } \\
\text { open ileocolic resection }\end{array}$ & $\begin{array}{l}\text { No significant } \\
\text { difference in clinical } \\
\text { and surgical POR rates } \\
\text { between two groups }\end{array}$ \\
\hline McLeod et al [89] & 2009 & $\begin{array}{l}\text { Multicenter } \\
\text { RCT }\end{array}$ & 139 & 1 & $\begin{array}{l}\text { Anastomotic configuration: } \\
\text { Patients were randomized } \\
\text { to undergo stapled SSA or } \\
\text { hand-sewn EEA } \\
\text { Others: Duration of } \\
\text { disease, number of } \\
\text { previous resections, } \\
\text { laparoscopic vs. open } \\
\text { procedure, smoking, } \\
\text { fistula or abscess present } \\
\text { at surgery, length of } \\
\text { small bowel affected, } \\
\text { postoperative azathioprine } \\
\text { therapy, compliance with } \\
\text { postoperative azathioprine } \\
\text { therapy, CDAI at six weeks }\end{array}$ & $\begin{array}{l}\text { Rates for endoscopic } \\
\text { and symptomatic } \\
\text { recurrence were similar } \\
\text { for SSA and EEA } \\
\text { Predictors for POR } \\
\text { Previous resections for } \\
\text { both endoscopic and } \\
\text { symptomatic POR. } \\
\text { Non-compliance } \\
\text { with postoperative } \\
\text { maintenance therapy }\end{array}$ \\
\hline Greenstein et al [111] & 2009 & $\begin{array}{l}\text { Single-center } \\
\text { retrospective }\end{array}$ & 88 & 6.9 & $\begin{array}{l}\text { Number of strictures / } \\
\text { strictureplasties performed } \\
\text { in each patient } \\
\text { Others: age, smoking, } \\
\text { preoperative use of } \\
\text { steroid or total parenteral } \\
\text { nutrition, prior intestinal } \\
\text { resection, concomitant } \\
\text { intestinal resection }\end{array}$ & $\begin{array}{l}\text { Number of strictures } \\
\text { / strictureplasties is } \\
\text { associated with surgical } \\
\text { POR rates: increase } \\
\text { in POR for each } \\
\text { additional stricture / } \\
\text { strictureplasty is } 7 \% \\
\text { and } 23 \% \text { respectively } \\
\text { No other predictor for } \\
\text { POR was found }\end{array}$ \\
\hline
\end{tabular}


Table 4 (Continued)

\begin{tabular}{|c|c|c|c|c|c|c|}
\hline Study & Year & Study design & $\begin{array}{l}\text { No of } \\
\text { patients }\end{array}$ & $\begin{array}{l}\text { Mean follow } \\
\text { up (years) }\end{array}$ & $\begin{array}{l}\text { Potential risk factors } \\
\text { evaluated }\end{array}$ & Results \\
\hline Stocchi et al [100] & 2008 & $\begin{array}{l}\text { Single-center } \\
\text { RCT }^{* *}\end{array}$ & 56 & 10.5 & $\begin{array}{l}\text { Surgical procedure: } \\
\text { Patients were randomized } \\
\text { to laparoscopic or open } \\
\text { ileocolic resection }\end{array}$ & $\begin{array}{l}\text { No significant } \\
\text { difference in } \\
\text { endoscopic, } \\
\text { radiological and } \\
\text { surgical POR rates } \\
\text { between two groups }\end{array}$ \\
\hline Scarpa et al [85] & 2007 & $\begin{array}{l}\text { Single-center } \\
\text { Retrospective }\end{array}$ & 141 & 3.2 & $\begin{array}{l}\text { Surgical: Laparoscopy vs. } \\
\text { laparotomy, anastomosis } \\
\text { type (stapled-SSA vs. hand- } \\
\text { sewn-SSA vs. stapled-ESA), } \\
\text { duration of the operation, } \\
\text { duration of the post- } \\
\text { operative hospital stay, day } \\
\text { of first bowel movement, } \\
\text { post-operative surgical and } \\
\text { intestinal complications } \\
\text { Non-surgical: sex, age at } \\
\text { operation, CD duration, } \\
\text { age at CD onset, recurrent } \\
\text { CD, CD phenotype, } \\
\text { medical therapy }\end{array}$ & $\begin{array}{l}\text { Predictors for POR } \\
\text { Surgical: } \\
\text { Anastomosis type; } \\
\text { ESA was associated } \\
\text { with increased risk for } \\
\text { surgical POR compared } \\
\text { to SSA (hand-sewn or } \\
\text { stapled) } \\
\text { Postoperative } \\
\text { complications for } \\
\text { symptomatic and } \\
\text { surgical POR } \\
\text { Non-surgical: } \\
\text { Young age at onset of } \\
\text { CD for surgical POR }\end{array}$ \\
\hline Muñoz-Juárez et al [88] & 2001 & $\begin{array}{l}\text { Multicenter } \\
\text { retrospective }\end{array}$ & 138 & $\begin{array}{l}5.8(\text { EEA }) / 3.8 \\
(\text { SSA })\end{array}$ & $\begin{array}{l}\text { Anastomotic configuration: } \\
\text { EEA vs. SSA }\end{array}$ & $\begin{array}{l}\text { EEA was associated } \\
\text { with higher risk for } \\
\text { surgical POR }\end{array}$ \\
\hline Fazio et al [97] & 1996 & $\begin{array}{l}\text { Single-center } \\
\text { RCT }\end{array}$ & 131 & 4.6 & $\begin{array}{l}\text { Patients were randomized } \\
\text { to undergo resection with } \\
\text { limited or extended }(2 \mathrm{~cm} \\
\text { or } 12 \mathrm{~cm} \text { respectively) } \\
\text { resection margin from } \\
\text { macroscopically diseased } \\
\text { bowel } \\
\text { Others: The presence of } \\
\text { microscopic findings of } \\
\mathrm{CD} \text { at resection margins, } \\
\text { age at the time of surgery, } \\
\text { sex, duration of CD, extent } \\
\text { of disease, indication for } \\
\text { surgery, location of CD, } \\
\text { prior resections }\end{array}$ & $\begin{array}{l}\text { Extended resection } \\
\text { margins were not } \\
\text { associated with } \\
\text { decreased risk for } \\
\text { clinical/surgical POR } \\
\text { Microscopic } \\
\text { involvement of margins } \\
\text { did not increase the risk } \\
\text { for POR } \\
\text { No other predictor for } \\
\text { POR was found }\end{array}$ \\
\hline D’Haens et al [98] & 1995 & $\begin{array}{l}\text { Single-center } \\
\text { retrospective }\end{array}$ & 23 & 2.5 & Extent of resection & $\begin{array}{l}\text { The length of intestinal } \\
\text { resection is correlated } \\
\text { with a shorter interval } \\
\text { to POR as well as the } \\
\text { extent of recurrent CD }\end{array}$ \\
\hline Scott et al [121] & 1991 & $\begin{array}{l}\text { Single-center } \\
\text { retrospective }\end{array}$ & 197 & 7.7 & $\begin{array}{l}\text { Blood transfusion as a } \\
\text { protective factor against } \\
\text { POR }\end{array}$ & $\begin{array}{l}\text { No protective effect } \\
\text { for perioperative } \\
\text { blood transfusion was } \\
\text { documented }\end{array}$ \\
\hline
\end{tabular}

${ }^{*}$ Long-term outcomes of Maastense's controlled randomized trial [102]

${ }^{* *}$ Long-term outcomes of Milsom's controlled randomized trial [101]

$C D$, Crohn's disease; POR, postoperative recurrence; EIM, extraintestinal manifestation; RCT, randomized controlled trial; CDAI, Crohn's disease activity index; SSA, side-to-side anastomosis; EEA, end-to-end anastomosis; ESA, end-to-side anastomosis

plexuses of bowel wall and POR. In 2006, Ferrante et al examined 59 ileocolonic specimens from CD patients. They found that myenteric plexitis (defined as the presence of at least one inflammatory cell in an enteric ganglion or nerve bundle) at the proximal resection margin was a predictive factor for early endoscopic recurrence at 3 (OR 4.36, 95\%CI 1.44-13.23, $\mathrm{P}=0.008)$ and 12 (OR 9.80, 95\%CI 1.04-92.70, $\mathrm{P}=0.041$ ) months. Moreover, the severity of inflammation (the 
authors created a 3-level scale of severity, according to the number of inflammatory cells involved in the most severely inflamed enteric ganglion or nerve bundle) was associated with the severity of recurrence according to Rutgeerts' scale. Interestingly, no correlation with POR rate was documented for submucosal plexitis, the type of inflammatory cells involved, or the presence of plexitis in the body of the specimen or the distal margin [125]. Ng et al evaluated the impact of clinical features on the rate of myenteric plexitis in 99 patients, finding that previous resections and shorter disease duration were predictors of proximal margin myenteric plexitis. Clinical recurrence 1 year after resection was $30 \%$ for the plexitis group and $16 \%$ for patients without this feature $(\mathrm{P}=0.14)$ [126].

A subsequent study by Sokol $(n=171)$ found that submucosal plexitis (with $\geq 3$ mastocytes) was a risk factor for early clinical recurrence (HR 1.87, 95\%CI 1.00-3.46, $\mathrm{P}=0.048$ ), whereas Bressenot $(n=67)$ reported an HR 8.02 (95\%CI 1.8734.47, $\mathrm{P}=0.0054)$ if submucosal plexitis involved $\geq 1$ eosinophil and 5.84 (95\%CI $1.23-27.65, \mathrm{P}=0.0269)$ if $\geq 6$ lymphocytes were involved $[127,128]$. Recently, a study of 86 CD ileocecal specimens showed that severe myenteric plexitis was a risk factor for surgical recurrence $(\mathrm{P}=0.035)$, whereas mild and moderate grade did not reach statistical significance [129]. A French cohort study in 2016 (75 patients) confirmed previous studies, finding that myenteric plexitis is an independent risk factor for endoscopic and surgical recurrence. Nevertheless, no impact of submucosal plexitis was found [130]. Recent data from a prospective study in Belgium (74 patients) correlated lymphocyte-induced submucosal plexitis with endoscopic recurrence $(\mathrm{P}=0.02)$ [131].

A constant finding in all studies was that plexitis is more frequent in the proximal than in the distal margin, leading authors to point out that this finding is in accordance with the fact that $\mathrm{CD}$ recurs proximally to the anastomosis, in the neoterminal ileum. Another remarkable finding is that the lymphocyte is the predominant cell in the inflammatory process of plexitis. The literature provides sufficient data about the correlation of enteric nervous system inflammation, especially myenteric plexitis, with POR as a risk factor.

\section{Granulomas}

The presence of granulomas in the bowel specimen is a frequent finding, but the significance of this feature in relation to POR rates remains unclear. Two early studies suggested that granulomas were associated with a lower risk of POR: Glass et al demonstrated that granulomatous disease was associated with half the risk for POR compared to non-granulomatous CD [132], and Champers reported a better prognosis only when granulomas were located in the large bowel and anus [133]. In contrast, subsequent studies have correlated granulomas with higher POR rates [134-136]. A retrospective study in the Mayo Clinic, USA, with 89 patients, found that granulomas were associated with an HR 2.89 (95\%CI 1.26-6.64, P=0.01) for POR [136].
Two recent studies found no impact on POR [43,137], whereas Li et al demonstrated higher endoscopic and surgical recurrence rates only when granulomas were located in the mesenteric lymph nodes [138]. In 2014, VanDussen correlated the proportion of abnormal Paneth cells in the specimen inversely with the presence of granulomas, but with a shorter interval for POR [139]. A meta-analysis by Similis, including 22 studies, concluded that granulomatous $\mathrm{CD}$ increases the risk of recurrence (OR 1.37, 95\%CI 1.02-1.84, $\mathrm{P}=0.04)$ and reoperation ( $\mathrm{OR} 2.38,95 \% \mathrm{CI} 1.43-3.95, \mathrm{P}<0.001$ ), although the heterogeneity of the studies included necessitates further confirmation [140]. Thus, the ECCO guidelines include the presence of granulomas as a risk factor for POR [78].

\section{Lymphatic vessel density}

Rahier et al, after examining the ileal and colonic specimens of $22 \mathrm{CD}$ patients, found that lymphatic vessel density was increased in all layers of ileal wall (although statistical significance was reached only for mucosa), as well as the mucosa and muscularis propria of colonic wall, including both inflamed and uninflamed areas [141]. In a subsequent study, the same authors evaluated the relationship between this feature and POR in 28 patients. It was shown that the decreased lymphatic density in mucosa and submucosa at the proximal margin of an ileocolonic specimen is associated with a high risk for early endoscopic recurrence. It was also demonstrated that lymphatic density $>7 \%$ in the mucosa was a predictor of non-recurrence, with a sensitivity and specificity of $81 \%$ and $75 \%$, respectively [142]. Further studies are needed in order to establish this feature as a predictive factor for POR.

\section{Gene-related factors} Nucleotide-binding oligomerization domain 2 (NOD2)/
caspase activation and recruitment domain 15 (CARD15)

NOD2 gene, also known as CARD15, is one of the most studied genes in IBD patients. Its mutations have been associated with CD development, as well as CD phenotype: it is a predictor of ileal stenotic disease, aggressive behavior and early ileocecal resection $[83,143]$. Its value as a prognostic factor for POR has been evaluated in the literature. In 2001, Alvarez-Lobos et al presented the results of 170 patients, correlating NOD2 variants with a higher risk of surgical POR and a shorter interval to reoperation [144]. Subsequent studies came to similar conclusions [145]. Another study from Germany demonstrated that homozygous patients for frameshift mutation 1007fs had a higher risk of POR [146]. Renda et al confirmed that only the $1007 \mathrm{fs}$ mutation had a predictive value for surgical POR (HR 2.9, 95\%CI 1.1-7.3, $\mathrm{P}=0.03$ ) [147]. Interestingly, a study by VanDussen correlated NOD2 mutations with a greater proportion of abnormal Paneth cells, a lower presence of granulomas in specimen and a higher risk for POR [139]. 
On the other hand, Manconi et al did not document an increased risk for reoperation for NOD2 variants; nor did a recent study by Fowler et al $[148,149]$. A meta-analysis by Solon et al concluded that a higher portion of NOD2 mutation carriers, compared to non-carriers, had surgical recurrence, but the finding was not statistically significant - this could be attributable to the heterogeneity of the six studies included [150]. Obviously, further data will be required to clarify the predictive value of NOD2 mutations for POR.

\section{Other genes}

Several other genetic loci have been assessed in the literature as potential risk factors, but the number of studies is limited, requiring additional data. For example, Meresse et al demonstrated that patients with low production of the anti-inflammatory cytokine interleukin (IL)-10 had a higher risk for endoscopic POR, although none of the IL-10 promoter polymorphisms that control IL-10 production were associated [151]. Sehgal et al, in a study of 66 patients, reported that a specific polymorphism at immunity-related GTPase family M gene (IRGFM) increased the risk for frequent intestinal resections [152]. Recently, a French study (137 patients) found that caspase recruitment domain-containing protein 8 gene mutations (CARD8) were predictors of higher rates for surgical recurrence in homozygous patients (OR 7.56, 95\%CI 1.1350.37, $\mathrm{P}=0.036$ ), whereas Fowler et al (194 patients) reported an increased risk for surgical recurrence in $S M A D 3$ gene mutation carriers (HR 4.04, 95\%CI 1.77-9.21, $\mathrm{P}=0.001$ ) [149,153].

\section{Postoperative management}

The ECCO-IBD guidelines published in 2016 for the diagnosis and treatment of $\mathrm{CD}$ recognize the following prognostic factors for early recurrence after ileocolonic resection: smoking, prior intestinal resection, absence of prophylactic treatment, perforating phenotype, extensive small bowel resection $(>50 \mathrm{~cm})$, perianal disease, granulomas, and myenteric plexitis at the proximal margin of the specimen [78] (Table 5). Therefore, the proper management after resection is fundamental for minimizing the recurrence rates.

Current literature data demonstrate that postoperative treatment with anti-TNF agents or thiopurines (azathioprine, 6-mercaptopurine) can reduce the risk of POR [154]. According to a subanalysis of the POCER study, adalimumab was superior to thiopurines in terms of decreasing the risk of POR [155]. Likewise, two meta-analyses have documented superiority of anti-TNF treatment over other therapeutic strategies, including thiopurines [156,157]. On the other hand, in a recent multicenter randomized trial (91 patients) comparing adalimumab to azathioprine, non-superiority of one strategy over the other was documented, although adalimumab was associated with better tolerance. In this study, patients were not recruited according to their risk for POR [158].

Nitroimidazole antibiotics (metronidazole, ornidazole) are effective in preventing short-term endoscopic and clinical POR when administered in the early postoperative period according to two randomized trials $[159,160]$. Bad tolerance, which led a statistically significant portion of patients to therapy discontinuation, as well as the fact that the protective effect lasts only for the period of drug administration, were documented in both studies. To date, administration for a short period postoperatively, in combination with other medication or not, is an option [161].

Table 5 Predictors of POR and their importance

\begin{tabular}{ll}
\hline Predictor & Importance \\
\hline Smoking & $\begin{array}{l}\text { Well-recognized and modifiable risk factor for POR } \\
\text { Smoking cessation reduces the risk to the levels of non-smokers }\end{array}$ \\
\hline Perforating phenotype & $\begin{array}{l}\text { Well-established predictor for POR } \\
\text { Penetrating disease usually reappears with the same behavior }\end{array}$ \\
\hline $\begin{array}{l}\text { Perianal disease } \\
\text { Extensive small bowel resection }(>50 \mathrm{~cm})\end{array}$ & $\begin{array}{l}\text { A consistent risk factor for POR } \\
\text { Prior intestinal resection }\end{array}$ \\
\hline Myenteric plexitis & $\begin{array}{l}\text { Limited data define prior resections as a predictor for POR } \\
\text { More frequent in proximal margin; association with CD recurrence proximally to the anastomosis }\end{array}$ \\
& $\begin{array}{l}\text { Lymphocytes are the predominant inflammatory cells } \\
\text { Further data for submucosal plexitis are necessary }\end{array}$ \\
\hline Granulomas & Heterogeneity of studies necessitate further confirmation of granulomas as a predictor for POR \\
\hline Absence of prophylactic treatment & $\begin{array}{l}\text { Appropriate management after resection depending on: } \\
\text { a. Risk stratification } \\
\text { b. Colonoscopy at 6-12 months reduces the risk for POR }\end{array}$ \\
\hline
\end{tabular}

POR, postoperative recurrence; $C D$, Crohn's disease 
Evidence relating to 5-aminosalicylates demonstrate that mesalamine is a well-tolerated medication, offering only a marginal protective effect for POR. Other medical treatments, such as corticoids or probiotics, have shown no benefit in reducing the risk for POR [154].

The landmark POCER trial demonstrated that estimation of the risk of recurrence, according to established risk factors, in combination with the findings at first postoperative colonoscopy (at 6 months), is mandatory for therapeutic decisions, and is associated with better outcomes than conventional treatment [12]. High-risk patients ( $\geq 1$ known risk factor) received thiopurines after surgery, escalating to anti-TNF only if index colonoscopy at six months revealed recurrence (Rutgeerts score $\geq i 2$ ). According to the authors, anti-TNF therapy for all high-risk patients increases the cost and is related with side effects, possibly overtreating a proportion of patients [12]. Another multicenter randomized control trial, although prematurely terminated because of slow recruitment, compared standard treatment with azathioprine in all high-risk patients versus endoscopy-tailored therapy. The findings demonstrated non-superiority of one strategy over the other [162].

According to the evidence above, postoperative management consists of two significant variables: POR risk stratification and early endoscopic assessment of the anastomosis (6-12 months postoperatively) for all patients. The POR risk indicates which patients should start medical treatment immediately after surgery, whereas early colonoscopy can find indices of early recurrence, leading to the appropriate adjustment of medical management. Anti-TNF agents, as well as thiopurines, seem to have an important protective value, currently being the drugs of choice for high- risk patients. Further data about the cost-effectiveness, as well as the potential of new biologics are expected. For low-risk patients, no medical treatment until colonoscopy at 6 months after surgery is the proposed approach [154].

\section{Concluding remarks}

The natural history of CD teaches us that surgical intervention cannot cure the disease. The proper management postoperatively is defined by risk stratification. Smoking, prior resection, penetrating behavior, perianal disease, extensive resections, granulomas and myenteric plexitis are well-established risk factors. Patients should be strongly encouraged to quit smoking at the onset of the disease, while a multidisciplinary approach (gastroenterologists, surgeons, pathologists, radiologists) is mandatory. Early endoscopic diagnosis of POR is another key point; therefore, patients should be aware of the intense postoperative follow up that is always necessary. In the future, further details from the genotype-phenotype correlation are expected to clarify the pathophysiology of recurrence, as well as allowing the development of new, more efficient therapeutic protocols.

\section{References}

1. Bernstein CN, Blanchard JF, Rawsthorne P, Yu N. The prevalence of extraintestinal diseases in inflammatory bowel disease: a population-based study. Am J Gastroenterol 2001;96:1116-1122.

2. Peyrin-Biroulet L, Loftus EV Jr, Colombel JF, Sandborn WJ. The natural history of adult Crohn's disease in population-based cohorts. Am J Gastroenterol 2010;105:289-297.

3. Bouguen G, Peyrin-Biroulet L. Surgery for adult Crohn's disease: what is the actual risk? Gut 2011;60:1178-1181.

4. Frolkis AD, Dykeman J, Negrón ME, et al. Risk of surgery for inflammatory bowel diseases has decreased over time: a systematic review and meta-analysis of population-based studies. Gastroenterology 2013;145:996-1006.

5. Ramadas AV, Gunesh S, Thomas GA, Williams GT, Hawthorne AB. Natural history of Crohn's disease in a population-based cohort from Cardiff (1986-2003): a study of changes in medical treatment and surgical resection rates. Gut 2010;59:1200-1206.

6. Lichtenstein GR, Yan S, Bala M, Blank M, Sands BE. Infliximab maintenance treatment reduces hospitalizations, surgeries, and procedures in fistulizing Crohn's disease. Gastroenterology 2005;128:862-869.

7. Buisson A, Chevaux JB, Allen PB, Bommelaer G, Peyrin-Biroulet L. Review article: the natural history of postoperative Crohn's disease recurrence. Aliment Pharmacol Ther 2012;35:625-633.

8. Frolkis AD, Lipton DS, Fiest KM, et al. Cumulative incidence of second intestinal resection in Crohn's disease: a systematic review and meta-analysis of population-based studies. Am J Gastroenterol 2014;109:1739-1748.

9. Swoger JM, Regueiro M. Evaluation for postoperative recurrence of Crohn disease. Gastroenterol Clin North Am 2012;41:303-314.

10. Rutgeerts P, Geboes K, Vantrappen G, Beyls J, Kerremans R, Hiele M. Predictability of the postoperative course of Crohn's disease. Gastroenterology 1990;99:956-963.

11. Boucher AL, Pereira B, Decousus S, et al. Endoscopy-based management decreases the risk of postoperative recurrences in Crohn's disease. World J Gastroenterol 2016;22:5068-5078.

12. De Cruz P, Kamm MA, Hamilton AL, et al. Crohn's disease management after intestinal resection: a randomised trial. Lancet 2015;385:1406-1417.

13. Hashash JG, Binion DG. Endoscopic evaluation and management of the postoperative Crohn's disease patient. Gastrointest Endosc Clin N Am 2016;26:679-692.

14. Domènech E, Mañosa $\mathrm{M}$, Bernal I, et al. Impact of azathioprine on the prevention of postoperative Crohn's disease recurrence: results of a prospective, observational, long-term follow-up study. Inflamm Bowel Dis 2008;14:508-513.

15. Bayart P, Duveau N, Nachury M, et al. Ileal or anastomotic location of lesions does not impact rate of postoperative recurrence in Crohn's disease patients classified i2 on the Rutgeerts score. Dig Dis Sci 2016;61:2986-2992.

16. Daperno $\mathrm{M}$, Comberlato $\mathrm{M}$, Bossa $\mathrm{F}$, et al. Inter-observer agreement in endoscopic scoring systems: preliminary report of an ongoing study from the Italian Group for Inflammatory Bowel Disease (IG-IBD). Dig Liver Dis 2014;46:969-973.

17. Marteau P, Laharie D, Colombel JF, et al; GETAID. Interobserver variation study of the Rutgeerts score to assess endoscopic recurrence after surgery for Crohn's disease. J Crohns Colitis 2016;10:1001-1005.

18. Yamamoto T. Diagnosis and monitoring of postoperative recurrence in Crohn's disease. Expert Rev Gastroenterol Hepatol 2015;9:55-66.

19. Pons Beltrán V, Nos P, Bastida G, et al. Evaluation of postsurgical recurrence in Crohn's disease: a new indication for capsule endoscopy? Gastrointest Endosc 2007;66:533-540.

20. Boschetti G, Laidet M, Moussata D, et al. Levels of fecal calprotectin 
are associated with the severity of postoperative endoscopic recurrence in asymptomatic patients with Crohn's disease. Am J Gastroenterol 2015;110:865-872.

21. Wright EK, Kamm MA, De Cruz P, et al. Measurement of fecal calprotectin improves monitoring and detection of recurrence of Crohn's disease after surgery. Gastroenterology 2015;148:938-947.

22. Qiu Y, Mao R, Chen BL, et al. Fecal calprotectin for evaluating postoperative recurrence of Crohn's disease: a meta-analysis of prospective studies. Inflamm Bowel Dis 2015;21:315-322.

23. Garcia-Planella E, Mañosa M, Cabré E, et al. Fecal calprotectin levels are closely correlated with the absence of relevant mucosal lesions in postoperative Crohn's disease. Inflamm Bowel Dis 2016;22:2879-2885.

24. Herranz Bachiller MT, Barrio Andres J, Fernandez Salazar L, RuizZorrilla R, Sancho Del Val L, Atienza Sanchez R. The utility of faecal calprotectin to predict post-operative recurrence in Crohn's disease. Scand J Gastroenterol 2016;51:720-726.

25. Regueiro M, Kip KE, Schraut W, et al. Crohn's disease activity index does not correlate with endoscopic recurrence one year after ileocolonic resection. Inflamm Bowel Dis 2011;17:118-126.

26. Walters TD, Steinhart AH, Bernstein $\mathrm{CN}$, et al. Validating Crohn's disease activity indices for use in assessing postoperative recurrence. Inflamm Bowel Dis 2011;17:1547-1556.

27. Miranda-García P, Chaparro M, Gisbert JP. Correlation between serological biomarkers and endoscopic activity in patients with inflammatory bowel disease. Gastroenterol Hepatol 2016;39:508-515.

28. Lobatón T, López-García A, Rodríguez-Moranta F, Ruiz A, Rodríguez L, Guardiola J. A new rapid test for fecal calprotectin predicts endoscopic remission and postoperative recurrence in Crohn's disease. J Crohns Colitis 2013;7:e641-e651.

29. Papamichael K, Karatzas P, Mantzaris GJ. Faecal calprotectin but not C-reactive protein (CRP) or Crohn's Disease Activity Index (CDAI) may predict post-operative endoscopic recurrence of Crohn's disease. J Crohns Colitis 2013;7:e700-e701.

30. Calabrese E, Petruzziello C, Onali S, et al. Severity of postoperative recurrence in Crohn's disease: correlation between endoscopic and sonographic findings. Inflamm Bowel Dis 2009;15:1635-1642.

31. Pallotta N, Giovannone M, Pezzotti P, et al. Ultrasonographic detection and assessment of the severity of Crohn's disease recurrence after ileal resection. BMC Gastroenterol 2010;10:69.

32. Paparo F, Revelli M, Puppo C, et al. Crohn's disease recurrence in patients with ileocolic anastomosis: value of computed tomography enterography with water enema. Eur J Radiol 2013;82:e434-e440.

33. Sailer J, Peloschek P, Reinisch W, Vogelsang H, Turetschek K, Schima W. Anastomotic recurrence of Crohn's disease after ileocolic resection: comparison of MR enteroclysis with endoscopy. Eur Radiol 2008;18:2512-2521.

34. Kennelly RP, Subramaniam T, Egan LJ, Joyce MR. Smoking and Crohn's disease: active modification of an independent risk factor (education alone is not enough). J Crohns Colitis 2013;7:631-635.

35. To N, Gracie DJ, Ford AC. Systematic review with meta-analysis: the adverse effects of tobacco smoking on the natural history of Crohn's disease. Aliment Pharmacol Ther 2016;43:549-561.

36. Ott C, Takses A, Obermeier F, Schnoy E, Müller M. Smoking increases the risk of extraintestinal manifestations in Crohn's disease. World J Gastroenterol 2014;20:12269-12276.

37. Sutherland LR, Ramcharan S, Bryant H, Fick G. Effect of cigarette smoking on recurrence of Crohn's disease. Gastroenterology 1990;98:1123-1128.

38. Yamamoto T, Keighley MR. The association of cigarette smoking with a high risk of recurrence after ileocolonic resection for ileocecal Crohn's disease. Surg Today 1999;29:579-580.

39. Yamamoto T, Allan RN, Keighley MR. Smoking is a predictive factor for outcome after colectomy and ileorectal anastomosis in patients with Crohn's colitis. Br J Surg 1999;86:1069-1070.

40. Kane SV, Flicker M, Katz-Nelson F. Tobacco use is associated with accelerated clinical recurrence of Crohn's disease after surgically induced remission. J Clin Gastroenterol 2005;39:32-35.

41. Cottone M, Rosselli M, Orlando A, et al. Smoking habits and recurrence in Crohn's disease. Gastroenterology 1994;106:643-648.

42. Unkart JT, Anderson L, Li E, et al. Risk factors for surgical recurrence after ileocolic resection of Crohn's disease. Dis Colon Rectum 2008;51:1211-1216.

43. de Barcelos IF, Kotze PG, Spinelli A, et al. Factors affecting the incidence of early endoscopic recurrence after ileocolonic resection for Crohn's disease: a multicentre observational study. Colorectal Dis 2017;19:O39-O45.

44. Manser CN, Frei P, Grandinetti T, et al; Investigators of the Swiss IBD Cohort Study. Risk factors for repetitive ileocolic resection in patients with Crohn's disease: results of an observational cohort study. Inflamm Bowel Dis 2014;20:1548-1554.

45. Ryan WR, Allan RN, Yamamoto T, Keighley MR. Crohn's disease patients who quit smoking have a reduced risk of reoperation for recurrence. Am J Surg 2004;187:219-225.

46. Reese GE, Nanidis T, Borysiewicz C, Yamamoto T, Orchard T, Tekkis PP. The effect of smoking after surgery for Crohn's disease: a meta-analysis of observational studies. Int $J$ Colorectal Dis 2008;23:1213-1221.

47. Timmer A, Sutherland LR, Martin F. Oral contraceptive use and smoking are risk factors for relapse in Crohn's disease. The Canadian Mesalamine for Remission of Crohn's Disease Study Group. Gastroenterology 1998;114:1143-1150.

48. Lindberg E, Järnerot G, Huitfeldt B. Smoking in Crohn's disease: effect on localisation and clinical course. Gut 1992;33:779-782.

49. Handler M, Dotan I, Klausner JM, Yanai H, Neeman E, Tulchinsky H. Clinical recurrence and re-resection rates after extensive vs. segmental colectomy in Crohn's colitis: a retrospective cohort study. Tech Coloproctol 2016;20:287-292.

50. Polle SW, Slors JF, Weverling GJ, Gouma DJ, Hommes DW, Bemelman WA. Recurrence after segmental resection for colonic Crohn's disease. Br J Surg 2005;92:1143-1149.

51. Margagnoni G, Aratari A, Mangone M, et al. Natural history of ileo-caecal Crohn's disease after surgical resection. A long term study. Minerva Gastroenterol Dietol 2011;57:335-344.

52. Kurer MA, Stamou KM, Wilson TR, Bradford IM, Leveson SH. Early symptomatic recurrence after intestinal resection in Crohn's disease is unpredictable. Colorectal Dis 2007;9:567-571.

53. Silverberg MS, Satsangi J, Ahmad T, et al. Toward an integrated clinical, molecular and serological classification of inflammatory bowel disease: report of a Working Party of the 2005 Montreal World Congress of Gastroenterology. Can J Gastroenterol 2005;19 Suppl A:5A-36A.

54. Louis E, Van Kemseke C, Reenaers C. Necessity of phenotypic classification of inflammatory bowel disease. Best Pract Res Clin Gastroenterol 2011;25 Suppl 1:S2-S7.

55. Blonski W, Buchner AM, Lichtenstein GR. Clinical predictors of aggressive/disabling disease: ulcerative colitis and Crohn disease. Gastroenterol Clin North Am 2012;41:443-462.

56. Scarpa M, Angriman I, Barollo M, et al. Risk factors for recurrence of stenosis in Crohn's disease. Acta Biomed 2003;74 Suppl 2:80-83.

57. Wettergren A, Christiansen J. Risk of recurrence and reoperation after resection for ileocolic Crohn's disease. Scand J Gastroenterol 1991;26:1319-1322.

58. Caprilli R, Corrao G, Taddei G, Tonelli F, Torchio P, Viscido A. Prognostic factors for postoperative recurrence of Crohn's disease. Gruppo Italiano per lo Studio del Colon e del Retto (GISC). Dis Colon Rectum 1996;39:335-341.

59. Yamamoto T. Factors affecting recurrence after surgery for Crohn's disease. World J Gastroenterol 2005;11:3971-3979. 
60. Poggioli G, Laureti S, Selleri S, et al. Factors affecting recurrence in Crohn's disease. Results of a prospective audit. Int J Colorectal Dis 1996;11:294-298.

61. Griffiths AM, Wesson DE, Shandling B, Corey M, Sherman PM. Factors influencing postoperative recurrence of Crohn's disease in childhood. Gut 1991;32:491-495.

62. Swoger JM, Regueiro M. Preventive therapy in postoperative Crohn's disease. Curr Opin Gastroenterol 2010;26:337-343.

63. Borley NR, Mortensen NJ, Chaudry MA, et al. Recurrence after abdominal surgery for Crohn's disease: relationship to disease site and surgical procedure. Dis Colon Rectum 2002;45:377-383.

64. Romberg-Camps MJ, Dagnelie PC, Kester AD, et al. Influence of phenotype at diagnosis and of other potential prognostic factors on the course of inflammatory bowel disease. Am J Gastroenterol 2009; 104:371-383.

65. Morar PS, Faiz O, Hodgkinson JD, et al. Concomitant colonic disease (Montreal L3) and re-resectional surgery are predictors of clinical recurrence following ileocolonic resection for Crohn's disease. Colorectal Dis 2015;17:O247-O255.

66. Onali S, Petruzziello C, Calabrese E, et al. Frequency, pattern, and risk factors of postoperative recurrence of Crohn's disease after resection different from ileo-colonic. J Gastrointest Surg 2009;13:246-252.

67. Keh C, Shatari T, Yamamoto T, Menon A, Clark MA, Keighley MR. Jejunal Crohn's disease is associated with a higher postoperative recurrence rate than ileocaecal Crohn's disease. Colorectal Dis 2005;7:366-368.

68. Wolters FL, Russel MG, Sijbrandij J, et al. Phenotype at diagnosis predicts recurrence rates in Crohn's disease. Gut 2006;55:1124-1130.

69. Vester-Andersen MK, Vind I, Prosberg MV, et al. Hospitalisation, surgical and medical recurrence rates in inflammatory bowel disease 2003-2011-a Danish population-based cohort study. J Crohns Colitis 2014;8:1675-1683.

70. Chardavoyne R, Flint GW, Pollack S, Wise L. Factors affecting recurrence following resection for Crohn's disease. Dis Colon Rectum 1986;29:495-502.

71. Avidan B, Sakhnini E, Lahat A, et al. Risk factors regarding the need for a second operation in patients with Crohn's disease. Digestion 2005;72:248-253.

72. Sachar DB, Lemmer E, Ibrahim C, et al. Recurrence patterns after first resection for stricturing or penetrating Crohn's disease. Inflamm Bowel Dis 2009;15:1071-1075.

73. Hofer B, Böttger T, Hernandez-Richter T, Seifert JK, Junginger T. The impact of clinical types of disease manifestation on the risk of early postoperative recurrence in Crohn's disease. Hepatogastroenterology 2001;48:152-155.

74. Aeberhard P, Berchtold W, Riedtmann HJ, Stadelmann G. Surgical recurrence of perforating and nonperforating Crohn's disease. A study of 101 surgically treated Patients. Dis Colon Rectum 1996;39:80-87.

75. Yamamoto T, Allan RN, Keighley MR. Perforating ileocecal Crohn's disease does not carry a high risk of recurrence but usually represents as perforating disease. Dis Colon Rectum 1999;42:519-524.

76. Simillis C, Yamamoto T, Reese GE, et al. A meta-analysis comparing incidence of recurrence and indication for reoperation after surgery for perforating versus nonperforating Crohn's disease. Am J Gastroenterol 2008;103:196-205.

77. Pascua M, Su C, Lewis JD, Brensinger C, Lichtenstein GR. Metaanalysis: factors predicting post-operative recurrence with placebo therapy in patients with Crohn's disease. Aliment Pharmacol Ther 2008;28:545-556.

78. Gionchetti P, Dignass A, Danese S, et al; ECCO. $3^{\text {rd }}$ European Evidence-based Consensus on the Diagnosis and Management of Crohn's Disease 2016: Part 2: Surgical Management and Special Situations. J Crohns Colitis 2017;11:135-149.
79. Han YM, Kim JW, Koh SJ, et al. Patients with perianal Crohn's disease have poor disease outcomes after primary bowel resection. J Gastroenterol Hepatol 2016;31:1436-1442.

80. Bernell O, Lapidus A, Hellers G. Risk factors for surgery and recurrence in 907 patients with primary ileocaecal Crohn's disease. Br J Surg 2000;87:1697-1701.

81. Vantrappen G, Rutgeerts P. Recurrence of Crohn's lesions in the neoterminal ileum after ileal resection and ileocolonic anastomosis. Verh K Acad Geneeskd Belg 1990;52:373-382; discussion 383-385.

82. Rutgeerts P, Goboes K, Peeters M, et al. Effect of faecal stream diversion on recurrence of Crohn's disease in the neoterminal ileum. Lancet 1991;338:771-774.

83. De Cruz P, Kamm MA, Prideaux L, Allen PB, Desmond PV. Postoperative recurrent luminal Crohn's disease: a systematic review. Inflamm Bowel Dis 2012;18:758-777.

84. Fornaro R, Caratto E, Caratto M, et al. Post-operative recurrence in Crohn's disease. Critical analysis of potential risk factors. An update. Surgeon 2015;13:330-347.

85. Scarpa M, Ruffolo C, Bertin E, et al. Surgical predictors of recurrence of Crohn's disease after ileocolonic resection. Int $\mathrm{J}$ Colorectal Dis 2007;22:1061-1069.

86. Hashemi M, Novell JR, Lewis AA. Side-to-side stapled anastomosis may delay recurrence in Crohn's disease. Dis Colon Rectum 1998;41:1293-1296.

87. Tersigni R, Alessandroni L, Barreca M, Piovanello P, Prantera C. Does stapled functional end-to-end anastomosis affect recurrence of Crohn's disease after ileocolonic resection? Hepatogastroenterology 2003;50:1422-1425.

88. Muñoz-Juárez M, Yamamoto $\mathrm{T}$, Wolff $\mathrm{BG}$, Keighley MR. Wide-lumen stapled anastomosis vs. conventional end-to-end anastomosis in the treatment of Crohn's disease. Dis Colon Rectum 2001;44:20-25; discussion 25-26.

89. McLeod RS, Wolff BG, Ross S, Parkes R, McKenzie M; Investigators of the CAST Trial. Recurrence of Crohn's disease after ileocolic resection is not affected by anastomotic type: results of a multicenter, randomized, controlled trial. Dis Colon Rectum 2009;52:919-927.

90. Simillis C, Purkayastha S, Yamamoto T, Strong SA, Darzi AW, Tekkis PP. A meta-analysis comparing conventional end-to-end anastomosis vs. other anastomotic configurations after resection in Crohn's disease. Dis Colon Rectum 2007;50:1674-1687.

91. Kono T, Ashida T, Ebisawa Y, et al. A new antimesenteric functional end-to-end handsewn anastomosis: surgical prevention of anastomotic recurrence in Crohn's disease. Dis Colon Rectum 2011;54:586-592.

92. Kono T, Fichera A, Maeda K, et al. Kono-S anastomosis for surgical prophylaxis of anastomotic recurrence in Crohn's disease: an international multicenter study. J Gastrointest Surg 2016;20:783-790.

93. Michelassi F. Crohn's recurrence after intestinal resection and anastomosis. Dig Dis Sci 2014;59:1352-1353.

94. Wolff BG, Beart RW Jr, Frydenberg HB, Weiland LH, Agrez MV, Ilstrup DM. The importance of disease-free margins in resections for Crohn's disease. Dis Colon Rectum 1983;26:239-243.

95. Krause U, Ejerblad S, Bergman L. Crohn's disease. A long-term study of the clinical course in 186 patients. Scand J Gastroenterol 1985;20:516-524.

96. Limketkai BN, Parian AM, Shah ND, Colombel JF. Short bowel syndrome and intestinal failure in Crohn's disease. Inflamm Bowel Dis 2016;22:1209-1218.

97. Fazio VW, Marchetti F, Church M, et al. Effect of resection margins on the recurrence of Crohn's disease in the small bowel. A randomized controlled trial. Ann Surg 1996;224:563-571; discussion 571-573.

98. D’Haens GR, Gasparaitis AE, Hanauer SB. Duration of recurrent 
ileitis after ileocolonic resection correlates with presurgical extent of Crohn's disease. Gut 1995;36:715-717.

99. Dasari BV, McKay D, Gardiner K. Laparoscopic versus open surgery for small bowel Crohn's disease. Cochrane Database Syst Rev 2011;(1):CD006956.

100. Stocchi L, Milsom JW, Fazio VW. Long-term outcomes of laparoscopic versus open ileocolic resection for Crohn's disease: follow-up of a prospective randomized trial. Surgery 2008;144:622-627; discussion 627-628.

101. Milsom JW, Hammerhofer KA, Böhm B, Marcello P, Elson P, Fazio VW. Prospective, randomized trial comparing laparoscopic vs. conventional surgery for refractory ileocolic Crohn's disease. Dis Colon Rectum 2001;44:1-8.

102. Maartense S, Dunker MS, Slors JF, et al. Laparoscopic-assisted versus open ileocolic resection for Crohn's disease: a randomized trial. Ann Surg 2006;243:143-149; discussion 150-153.

103. Eshuis EJ, Slors JF, Stokkers PC, et al. Long-term outcomes following laparoscopically assisted versus open ileocolic resection for Crohn's disease. Br J Surg 2010;97:563-568.

104. Patel SV, Patel SV, Ramagopalan SV, Ott MC. Laparoscopic surgery for Crohn's disease: a meta-analysis of perioperative complications and long term outcomes compared with open surgery. BMC Surg 2013;13:14.

105. Ambe R, Campbell L, Cagir B. A comprehensive review of strictureplasty techniques in Crohn's disease: types, indications, comparisons, and safety. J Gastrointest Surg 2012;16:209-217.

106. Roy P, Kumar D. Strictureplasty for active Crohn's disease. Int J Colorectal Dis 2006;21:427-432.

107. Geltzeiler CB, Young JI, Diggs BS, et al. Strictureplasty for treatment of Crohn's disease: an ACS-NSQIP database analysis. J Gastrointest Surg 2015;19:905-910.

108. de Buck van Overstraeten A, Vermeire S, Vanbeckevoort D, et al. Modified side-to-side isoperistaltic strictureplasty over the ileocaecal valve: an alternative to ileocaecal resection in extensive terminal ileal Crohn's disease. J Crohns Colitis 2016;10:437-442.

109. Yamamoto T, Keighley MR. Long-term results of strictureplasty for ileocolonic anastomotic recurrence in Crohn's disease. J Gastrointest Surg 1999;3:555-560.

110. Dietz DW, Fazio VW, Laureti S, et al. Strictureplasty in diffuse Crohn's jejunoileitis: safe and durable. Dis Colon Rectum 2002;45:764-770.

111. Greenstein AJ, Zhang LP, Miller AT, et al. Relationship of the number of Crohn's strictures and strictureplasties to postoperative recurrence. J Am Coll Surg 2009;208:1065-1070.

112. Sampietro GM, Cristaldi M, Maconi G, et al. A prospective, longitudinal study of nonconventional strictureplasty in Crohn's disease. J Am Coll Surg 2004;199:8-20.

113. Fazi M, Giudici F, Luceri C, Pronestì M, Tonelli F. Long-term results and recurrence-related risk factors for Crohn disease in patients undergoing side-to-side isoperistaltic strictureplasty. JAMA Surg 2016;151:452-460.

114. Tichansky D, Cagir B, Yoo E, Marcus SM, Fry RD. Strictureplasty for Crohn's disease: meta-analysis. Dis Colon Rectum 2000;43:911-919.

115. Campbell L, Ambe R, Weaver J, Marcus SM, Cagir B. Comparison of conventional and nonconventional strictureplasties in Crohn's disease: a systematic review and meta-analysis. Dis Colon Rectum 2012;55:714-726.

116. Reese GE, Purkayastha S, Tilney HS, von Roon A, Yamamoto T, Tekkis PP. Strictureplasty vs resection in small bowel Crohn's disease: an evaluation of short-term outcomes and recurrence. Colorectal Dis 2007;9:686-694.

117. Yamamoto T, Fazio VW, Tekkis PP. Safety and efficacy of strictureplasty for Crohn's disease: a systematic review and metaanalysis. Dis Colon Rectum 2007;50:1968-1986.
118. Peters WR, Fry RD, Fleshman JW, Kodner IJ. Multiple blood transfusions reduce the recurrence rate of Crohn's disease. Dis Colon Rectum 1989;32:749-753.

119. Williams JG, Hughes LE. Effect of perioperative blood transfusion on recurrence of Crohn's disease. Lancet 1989;2:131-133.

120. Steup WH, Brand A, Weterman IT, Zwinderman KH, Lamers CB, Gooszen HG. The effect of perioperative blood transfusion on recurrence after primary operation for Crohn's disease. Scand J Gastroenterol Suppl 1991;188:81-86.

121. Scott AD, Ritchie JK, Phillips RK. Blood transfusion and recurrent Crohn's disease. Br J Surg 1991;78:455-458.

122. Hollaar GL, Gooszen HG, Post S, Williams JG, Sutherland LR. Perioperative blood transfusion does not prevent recurrence in Crohn's disease. A pooled analysis. J Clin Gastroenterol 1995;21:134-138.

123. Li Y, Stocchi L, Rui Y, et al. Perioperative blood transfusion and postoperative outcome in patients with Crohn's disease undergoing primary ileocolonic resection in the "Biological Era". J Gastrointest Surg 2015;19:1842-1851.

124. Ng SC, Lied GA, Arebi N, Phillips RK, Kamm MA. Clinical and surgical recurrence of Crohn's disease after ileocolonic resection in a specialist unit. Eur J Gastroenterol Hepatol 2009;21:551-557.

125. Ferrante M, de Hertogh G, Hlavaty T, et al. The value of myenteric plexitis to predict early postoperative Crohn's disease recurrence. Gastroenterology 2006;130:1595-1606.

126. Ng SC, Lied GA, Kamm MA, Sandhu F, Guenther T, Arebi N. Predictive value and clinical significance of myenteric plexitis in Crohn's disease. Inflamm Bowel Dis 2009;15:1499-1507.

127. Sokol H, Polin V, Lavergne-Slove A, et al. Plexitis as a predictive factor of early postoperative clinical recurrence in Crohn's disease. Gut 2009;58:1218-1225.

128. Bressenot A, Chevaux JB, Williet N, et al. Submucosal plexitis as a predictor of postoperative surgical recurrence in Crohn's disease. Inflamm Bowel Dis 2013;19:1654-1661.

129. Misteli H, Koh CE, Wang LM, Mortensen NJ, George B, Guy R. Myenteric plexitis at the proximal resection margin is a predictive marker for surgical recurrence of ileocaecal Crohn's disease. Colorectal Dis 2015;17:304-310.

130. Decousus S, Boucher AL, Joubert J, et al. Myenteric plexitis is a risk factor for endoscopic and clinical postoperative recurrence after ileocolonic resection in Crohn's disease. Dig Liver Dis 2016;48:753-758.

131. Lemmens B, de Buck van Overstraeten A, Arijs I, et al. Submucosal plexitis as a predictive factor for postoperative endoscopic recurrence in patients with Crohn's disease undergoing a resection with ileocolonic anastomosis: results from a prospective single-centre study. J Crohns Colitis 2017;11:212-220.

132. Glass RE, Baker WN. Role of the granuloma in recurrent Crohn's disease. Gut 1976;17:75-77.

133. Chambers TJ, Morson BC. The granuloma in Crohn's disease. Gut 1979;20:269-274.

134. Anseline PF, Wlodarczyk J, Murugasu R. Presence of granulomas is associated with recurrence after surgery for Crohn's disease: experience of a surgical unit. Br J Surg 1997;84:78-82.

135. Cullen G, O'Toole A, Keegan D, Sheahan K, Hyland JM, O'Donoghue DP. Long-term clinical results of ileocecal resection for Crohn's disease. Inflamm Bowel Dis 2007;13:1369-1373.

136. Malireddy K, Larson DW, Sandborn WJ, et al. Recurrence and impact of postoperative prophylaxis in laparoscopically treated primary ileocolic Crohn disease. Arch Surg 2010;145:42-47.

137. Denoya P, Canedo J, Berho M, et al. Granulomas in Crohn's disease: does progression through the bowel layers affect presentation or predict recurrence? Colorectal Dis 2011;13:1142-1147.

138. Li Y, Stocchi L, Liu X, et al. Presence of granulomas in mesenteric lymph nodes is associated with postoperative recurrence in 
Crohn's disease. Inflamm Bowel Dis 2015;21:2613-2618.

139. VanDussen KL, Liu TC, Li D, et al. Genetic variants synthesize to produce Paneth cell phenotypes that define subtypes of Crohn's disease. Gastroenterology 2014;146:200-209.

140. Simillis C, Jacovides M, Reese GE, Yamamoto T, Tekkis PP. Metaanalysis of the role of granulomas in the recurrence of Crohn disease. Dis Colon Rectum 2010;53:177-185.

141. Rahier JF, De Beauce S, Dubuquoy L, et al. Increased lymphatic vessel density and lymphangiogenesis in inflammatory bowel disease. Aliment Pharmacol Ther 2011;34:533-543.

142. Rahier JF, Dubuquoy L, Colombel JF, et al. Decreased lymphatic vessel density is associated with postoperative endoscopic recurrence in Crohn's disease. Inflamm Bowel Dis 2013;19:2084-2090.

143. Economou M, Trikalinos TA, Loizou KT, Tsianos EV, Ioannidis JP. Differential effects of NOD2 variants on Crohn's disease risk and phenotype in diverse populations: a metaanalysis. Am J Gastroenterol 2004;99:2393-2404.

144. Alvarez-Lobos M, Arostegui JI, Sans M, et al. Crohn's disease patients carrying Nod2/CARD15 gene variants have an increased and early need for first surgery due to stricturing disease and higher rate of surgical recurrence. Ann Surg 2005;242:693-700.

145. Büning C, Genschel J, Bühner S, et al. Mutations in the NOD2/ CARD15 gene in Crohn's disease are associated with ileocecal resection and are a risk factor for reoperation. Aliment Pharmacol Ther 2004;19:1073-1078.

146. Seiderer J, Schnitzler F, Brand S, et al. Homozygosity for the CARD15 frameshift mutation $1007 \mathrm{fs}$ is predictive of early onset of Crohn's disease with ileal stenosis, entero-enteral fistulas, and frequent need for surgical intervention with high risk of restenosis. Scand J Gastroenterol 2006;41:1421-1432.

147. Renda MC, Orlando A, Civitavecchia G, et al. The role of CARD15 mutations and smoking in the course of Crohn's disease in a Mediterranean area. Am J Gastroenterol 2008;103:649-655.

148. Maconi G, Colombo E, Sampietro GM, et al. CARD15 gene variants and risk of reoperation in Crohn's disease patients. Am J Gastroenterol 2009;104:2483-2491.

149. Fowler SA, Ananthakrishnan AN, Gardet A, et al. SMAD3 gene variant is a risk factor for recurrent surgery in patients with Crohn's disease. J Crohns Colitis 2014;8:845-851.

150. Solon JG, Burke JP, Walsh SR, Coffey JC. The effect of NOD2 polymorphism on postsurgical recurrence in Crohn's disease: a systematic review and meta-analysis of available literature. Inflamm Bowel Dis 2013;19:1099-1105.
151. Meresse B, Rutgeerts P, Malchow H, et al. Low ileal interleukin 10 concentrations are predictive of endoscopic recurrence in patients with Crohn's disease. Gut 2002;50:25-28.

152. Sehgal R, Berg A, Polinski JI, et al. Mutations in IRGM are associated with more frequent need for surgery in patients with ileocolonic Crohn's disease. Dis Colon Rectum 2012;55:115-121.

153. Germain A, Guéant RM, Chamaillard M, Bresler L, Guéant JL, Peyrin-Biroulet L. CARD8 gene variant is a risk factor for recurrent surgery in patients with Crohn's disease. Dig Liver Dis 2015;47:938-942.

154. Nguyen V, Kanth R, Gazo J, Sorrentino D. Management of postoperative Crohn's disease in 2017: where do we go from here? Expert Rev Gastroenterol Hepatol 2016;10:1257-1269.

155. De Cruz P, Kamm MA, Hamilton AL, et al. Efficacy of thiopurines and adalimumab in preventing Crohn's disease recurrence in high-risk patients - a POCER study analysis. Aliment Pharmacol Ther 2015;42:867-879.

156. Carla-Moreau A, Paul S, Roblin X, Genin C, Peyrin-Biroulet L. Prevention and treatment of postoperative Crohn's disease recurrence with anti-TNF therapy: a meta-analysis of controlled trials. Dig Liver Dis 2015;47:191-196.

157. Singh S, Garg SK, Pardi DS, Wang Z, Murad MH, Loftus EV Jr. Comparativeefficacyofpharmacologicinterventionsinpreventing relapse of Crohn's disease after surgery: a systematic review and network meta-analysis. Gastroenterology 2015;148:64-76.

158. Lopez-Sanroman A, Vera-Mendoza I, Domenech E, et al. Adalimumab vs azathioprine in the prevention of postoperative Crohn's disease recurrence. A geteccu randomized trial. J Crohns Colitis 2017 Apr 11. [Epub ahead of print] doi: 10.1093/ecco-jcc/ jjx051

159. Rutgeerts P, Van Assche G, Vermeire S, et al. Ornidazole for prophylaxis of postoperative Crohn's disease recurrence: a randomized, double-blind, placebo-controlled trial. Gastroenterology 2005;128:856-861.

160. Rutgeerts P, Hiele M, Geboes K, et al. Controlled trial of metronidazole treatment for prevention of Crohn's recurrence after ileal resection. Gastroenterology 1995;108:1617-1621.

161. Spinelli A, Sacchi M, Fiorino G, Danese S, Montorsi M. Risk of postoperative recurrence and postoperative management of Crohn's disease. World J Gastroenterol 2011;17:3213-3219.

162. Ferrante M, Papamichael K, Duricova D, et al; International Organization for Study of Inflammatory Bowel Diseases. Systematic versus endoscopy-driven treatment with azathioprine to prevent postoperative ileal Crohn's disease recurrence. J Crohns Colitis 2015;9:617-624. 